\title{
Isolation and Identification of Anticancer Apigenin Glycosides Flavonoids from Plantation White Sugar
}

\author{
VIKESH KUMAR \\ Department of Chemistry, Awadhesh Pratap Singh University, Rewa, Madhya Pradesh- 486003, India. \\ *Corresponding author E-mail: vikeshkumaraps@gmail.com
}

http://dx.doi.org/10.13005/ojc/360326

(Received: May 23, 2020; Accepted: June 20, 2020)

\begin{abstract}
Apigenin and its derivatives are biological active flavonoids that are useful in a variety of dietary constituents. These flavonoids may exert some influence over the transition from normal to cancerous, and have value as chemopreventive substance. In this study, a new purification method of three apigenin glycosides flavonoids from Indian plantation white sugar extracts was developed. Three unknown sugar flavonoids were isolated from sugar by using resin based column chromatography. After filtration, the colorant solution was adsorbed on to the gel column at a flow rate of $1 \mathrm{~mL} / 3 \mathrm{~min}$ and elution was done with water at the same rate. $10 \mathrm{~mL}$ fractions were collected which were then chromatographed on cellulose TLC plates. The pure fractions were completely evaporated and investigated for identification. The detected flavonoids were: apigenin-8-C-b-Dglucopyranoside, apigenin 6-C-b-glucopyranoside and apigenin-7-O-b-glucopyranoside. Ultraviolet and nuclear magnetic resonance spectroscopy introduces an additional analytical dimension for the identification of sugar flavonoids.
\end{abstract}

Keywords: Flavonoid, Sugarcane Plant Extract, Extraction, Resin.

\section{INTRODUCTION}

Sugarcane flavonoids receive considerable attention in the literature, because of their biological, chemotaxonomic markers and physiological importance ${ }^{1-2}$. Flavonoids are found in nearly every plant type and are ingested in diets routinely ${ }^{2}$. Flavonoids have frequently found in sugarcan $\mathrm{e}^{3-4}$, cane juice ${ }^{5-6}$, molasses $^{7}$, and mill syrup ${ }^{8}$. Sugarcane and cane juice contained various phenolics such as quercetin, rutin, morin, and ferulic acids and showed the antibiotic and antioxidant properties. ${ }^{9-10}$
The apigenin flavonoids also occur mainly as C-glycosides in sugarcane, with $\mathrm{C}-\mathrm{C}$ bonds at the 6 or 8 positions or both in the case of vicenins. Cane sugar by product may contain apigenin as it in case of other mill syrup and molasses. These phenomena developed from another studies dealing with apigenin 5-0-methyl ether in sugarcane flower ${ }^{11}$, apigenin 5-0-methyl ether 4'-0-galactoside in peelings ${ }^{12-13}$, apigenin 5,7-0- dimethyl ether 4'-01glucoside and apigenin-6-C-glucoside (Isovitexin) in leaf ${ }^{14}$, and apigenin-6-C-glucosyl-7-0-methyl ether, apigenin-6-C-glucosyl-8-C-arabinoside, apigenin-6-C-arabinosyl-8-C glucoside, apigenin6-C-arabinosyl-8-C glucoside in mill syrup ${ }^{15-16}$.

This is an Open Access article licensed under a Creative Commons license: Attribution 4.0 International (CC- BY). Published by Oriental Scientific Publishing Company @ 2018 
Vitexin, a flavonoid compound found in the sugarcane, possess to have anticancer ${ }^{17}$, antioxidant ${ }^{18}$, anti-viral ${ }^{19}$, anti-inflammatory ${ }^{20}$, antithyroid, anti-arteriosclerotic ${ }^{21}$, antihypertensive ${ }^{22}$ and antihepatotoxic properties ${ }^{23}$. Apigenin and its derivatives exist in sugarcane plants and are found at significant concentrations in many spices, fruits, and herbs ${ }^{24}$. In sugarcane,the well-known apigenin glycosides are apigenin-7-0-glucoside, apigenin-8C-glucoside, and apigenin-6-C-glucoside ${ }^{25}$.

Sugarcane flavonoids may interact with protein molecule and be eliminating protein those are broken during the digestion process ${ }^{26}$. Apigenin derived from sugarcane has been used to treat various diseases such as inflammatory, neuralgia, and shingles ${ }^{27}$. An Apigenin derivative has been reported as cancer chemopreventive agents and appears to confer protection against a large variety of cancer as reviewed ${ }^{28}$.

These flavonoids suppress cell cycle progression, including those of oral squamous carcinoma, esophageal, gastric, and cancer of organs associate with the gastrointestinal tract ${ }^{29}$. Additional clinical uses include antiviral and antihepatotoxic effects. The antioxidant activity of sugarcane flavonoids leads to the place and sequence of the $\mathrm{OH}$ group on the benzenoid ring that inhibits superoxide radicals ${ }^{30-32}$.

Rare features of flavonoids in sugar cane to develop flower color for entomophilic pollination. Sugarcane flavonoids (Flavonol, flavonone, chalcones) are mostly water soluble. Some flavonoids were identified in mill syrup, bagasse and sugarcane leaves ${ }^{33-34}$.

Many studies have shown that the sugarcane flavonoids possess antioxidant activities. Individual recovery of flavonoids from sugar has not been done yet. Thus, in this study, individual flavonoids components from plantation white sugar were separated by gel permeation technique and characterized by retardation factor, ultraviolet and nuclear magnetic resonance spectroscopy.

\section{EXPERIMENTAL}

${ }^{1} \mathrm{H}$ spectra of flavonoids were recorded using JEOL AL $500 \mathrm{MHz}$ spectrometer in DMSO-d ${ }_{6}$ containing TMS as internal standard reference. The UV-Vis measurements in the range of 200-800 $\mathrm{nm}$ were recorded using the Shimadzu UV-1601 spectrophotometer. Plantation white sugar was supplied by different sugar factories. Analytical grade solvents were used for sample preparation, purchased from Merck (Mumbai, India). For recovering of sugar flavonoids a XAD-4 macroporous adsorption resin (polystyrene resin, 20-60 mesh particle size, pore diameter $40 \mathrm{~A} 0$, surface area $=725$ $\mathrm{m}^{2} / \mathrm{g}$ ) was used.

\section{Preparation of Plantation white sugar}

A $25^{\circ} \mathrm{Bx}$ solution of plantation white sugar was filtered and the $\mathrm{pH}$ was adjusted to about 4 with concentrated $\mathrm{HCl}$.

\section{Extraction and Isolation}

A glass chromatography column $(300 \times 20$ $\mathrm{mm}$ ID), filled with XAD-4 resin was used for flavonoids adsorption. The column was activated with $4 \mathrm{BV}$ of $5 \%(\mathrm{v} / \mathrm{v}) \mathrm{HCl}$ and followed by $4 \mathrm{BV}$ of $5 \%(\mathrm{v} / \mathrm{v}) \mathrm{NaOH}$, and redistilled water to a neutral $\mathrm{pH}$. Initial concentration of plantation white sugar extract was $0.8 \mathrm{mg} / \mathrm{mL}, \mathrm{pH}$ of sugar solution was 7 ( 10 bed volume feeding solution; flow rate 2.5 bed volume per hour). For flavonoids recovery a mixture of methanol: ammonia: water (50:5:45) was used. The desorbed solution of colorants was completely evaporated under vacuum. The solid colorants were completely dried over $\mathrm{P}_{2} \mathrm{O}_{5}$ and weighed. The solid colorant was dissolved in about $100 \mathrm{~mL}$ water and 1-2 drops of concentrated $\mathrm{HCl}$ were added to precipitate any polymeric colorant ${ }^{35}$. After filtration, the colorant solution was adsorbed on to the gel column at a flow rate of $1 \mathrm{~mL} / 3 \mathrm{~min}$ and elution was done with water at the same rate. $10 \mathrm{~mL}$ fractions were collected which were then chromatographed on cellulose TLC plates. The pure fractions were completely evaporated and investigated for identification.

\section{RESULTS AND DISCUSSION}

The structural characterization of sugar afford three flavonoids (1-3), they are apigenin-8-C-b-D-glucopyranoside (1), apigenin6-C-b-glucopyranoside(2), and apigenin-7-O-b- 
glucopyranoside(3), their structure elucidation was carried out through Rf-values, color reactions (Table 1), and spectral analysis (UV and NMR) ${ }^{36}$.

Table 1: Rf values and spot appearance of flavonoids

\begin{tabular}{lccc}
\hline Compound & Rf value & UV light & UV/NH $\mathrm{NH}_{3}$ \\
\hline $\begin{array}{l}\text { Apigenin-8-C-b-D- } \\
\text { glucopyranoside }\end{array}$ & 0.43 (TBA) & Deep purple & Yellow-green \\
$\begin{array}{l}\text { Apigenin 6-C-b- } \\
\text { glucopyranoside }\end{array}$ & 0.57 (TBA) & Deep purple & Yellow-green \\
$\begin{array}{l}\text { Apigenin-7-O-b- } \\
\text { glucopyranoside }\end{array}$ & 0.61 (TBA) & Deep purple & Light yellow \\
\hline
\end{tabular}

Spectral data of the known sugar flavonoids were in good agreement with those previously published $^{11}$. Compounds 1, 2 and 3 were isolated for the first time from the sugar under investigation (Figure 1, 4, 7).

Compound 1(UV spectrum) shows two absorption peaks at $270,334 \mathrm{~nm}$ that matched with that reported for apigenin-8-C-b-D-glucopyranoside (Fig. 2). The data of the analysis for flavonoids characterization of sugar are shown in Table 2. The ${ }^{1} \mathrm{H}$ NMR spectra of compound 1 showed $\mathrm{H}-3$ and $\mathrm{H}-6$ signal at $\delta_{H} 6.59$ and 6.30 (each $1 \mathrm{H}$ ). An overlapping complex pattern between 7.7-7.9 (2H) for the C-2' and C-6' proton comprising an up field doublet at $6.87(\mathrm{~J}=8.4 \mathrm{~Hz})$ for the $\mathrm{C}-3^{\prime}$ and $\mathrm{C}-5^{\prime}$ proton. The ${ }^{1} \mathrm{H}$ NMR spectrum of compound 1 shows signal for 6"-O- methyl group at $\delta_{\mathrm{H}} 3.4^{36}$ (Figure 3).

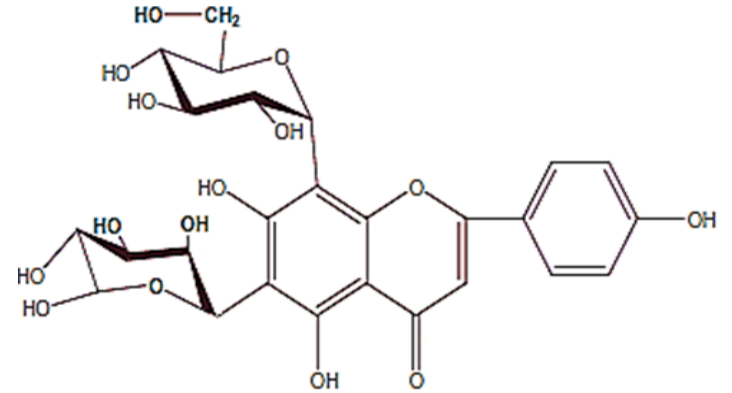

Fig. 1. Chemical structure of compound apigenin-8-C-b-Dglucopyranoside

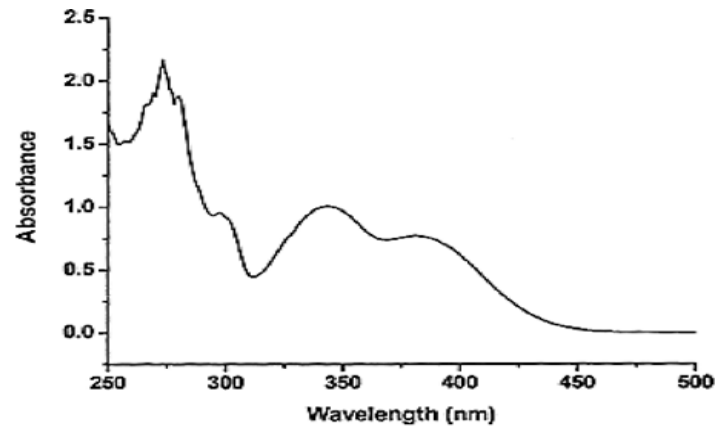

Fig. 2. UV spectrum of apigenin-8-C-b-D-glucopyranoside

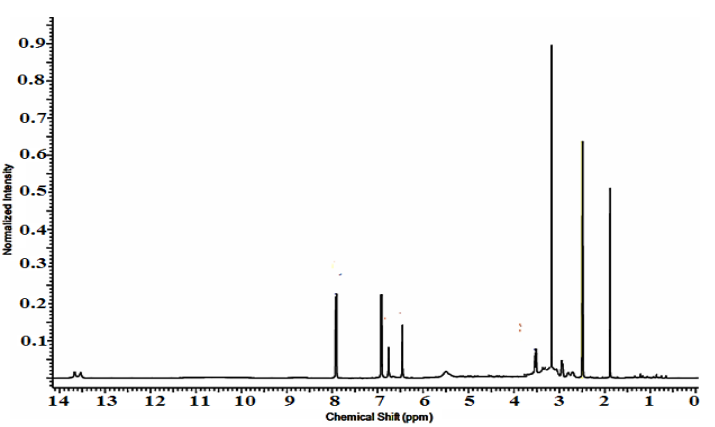

Fig. 3. NMR spectrum of apigenin-8-C-b-D-glucopyranoside

Table 2: The UV Characterization Data of Flavonoids in Plantation White Sugar

\begin{tabular}{|c|c|c|c|c|c|c|}
\hline Compound & $\begin{array}{l}\text { Methyl } \\
\text { Acohol }\end{array}$ & $\begin{array}{l}\text { Sodium } \\
\text { Methoxide }\end{array}$ & $\begin{array}{l}\text { Aluminum } \\
\text { Chloride }\end{array}$ & $\begin{array}{l}\text { Aluminum Chloride } \\
\text { /Hydrochloric Acid }\end{array}$ & $\begin{array}{l}\text { Sodium } \\
\text { Acetate }\end{array}$ & $\begin{array}{l}\text { Sodium Methoxide/ } \\
\text { Hydro Boric Acid }\end{array}$ \\
\hline Apigenin-8-C-b-D-glucopyranoside & $\begin{array}{c}270 \\
300 \mathrm{sh} \\
334\end{array}$ & $\begin{array}{l}280 \\
330 \\
394\end{array}$ & $\begin{array}{l}265 \\
274 \\
304 \\
350 \\
384\end{array}$ & $\begin{array}{c}258 \mathrm{sh} \\
280 \\
305 \\
344 \\
382\end{array}$ & $\begin{array}{c}275 \\
300 \text { sh } \\
378\end{array}$ & $\begin{array}{c}272 \\
316 \text { sh } \\
352\end{array}$ \\
\hline Apigenin 6-C-b-glucopyranoside & $\begin{array}{l}270 \\
330\end{array}$ & $\begin{array}{l}275 \\
330 \\
400\end{array}$ & $\begin{array}{c}265 \mathrm{sh} \\
280 \\
300 \\
350 \\
375\end{array}$ & $\begin{array}{c}264 \text { sh } \\
278 \\
300 \\
350\end{array}$ & $\begin{array}{l}280 \\
300 \\
380\end{array}$ & $\begin{array}{c}270 \\
350 \\
400 \text { sh }\end{array}$ \\
\hline Apigenin-7-O-b-glucopyranoside & $\begin{array}{l}266 \\
332\end{array}$ & $\begin{array}{c}250 \\
270 \\
300 \text { sh } \\
385\end{array}$ & $\begin{array}{c}273 \\
300 \mathrm{sh} \\
326 \\
430\end{array}$ & $\begin{array}{l}275 \\
295 \\
345 \\
380\end{array}$ & $\begin{array}{c}260 \\
265 \mathrm{sh} \\
355 \\
382\end{array}$ & $\begin{array}{l}265 \\
340\end{array}$ \\
\hline
\end{tabular}


Compound 2 UV-Vis maxima 270, 270 (shoulder), 330 and was ascribed to apigenin 6-Cb-glucopyranoside (Fig. 5). The ${ }^{1} \mathrm{H}$ NMR spectra of compound 2 indicated the presence of apigenin 6-Cb-glucopyranoside, chemical shift of $\mathrm{H}-3$, and $\mathrm{H}-8$ at $\delta_{\mathrm{H}} 6.71(1 \mathrm{H})$ and $6.50(1 \mathrm{H}, \mathrm{d}, \mathrm{J}=2.3)$. Two aromatic doublet at $\delta_{\mathrm{H}} 6.89$ and 7.86 (each $2 \mathrm{H}, \mathrm{d}, \mathrm{J}=8.4$ ) for C-3' and C-5' proton and one doublet at $\delta_{\mathrm{H}} 7.86$ for $\mathrm{C}-\mathrm{2}^{\prime}$ and $\mathrm{C}-\mathrm{6}^{\prime}$ proton and a methoxyl group at $\delta_{\mathrm{H}}$ 3.88 (Fig. 6). These results allowed us to establish apigenin 6 -C-b-glucopyranoside as the structure ${ }^{36}$ of compound 2.

Compound 3 shows UV-Vis maxima at 266 , 332 (Fig. 8). This compound was tentatively assigned as apigenin-7-O-b-glucopyranoside ${ }^{11}$. The ${ }^{1} \mathrm{H}$ NMR characterization of compound 3 shows an anomeric proton at $\delta_{\mathrm{H}} 5.08(1 \mathrm{H}, \mathrm{d}, \mathrm{J}=6.85)$. The compound 3 showed $\mathrm{H}-3$ and $\mathrm{H}-6$ at $\delta_{\mathrm{H}} 6.41$ and 6.61. ${ }^{1} \mathrm{HNMR}$ spectrum of compounds shows doublet at $6.9(1 \mathrm{H}$, $\mathrm{d}, \mathrm{J}=2.3 \mathrm{~Hz}$ ) for C-3' and C-5' proton. Doublet at $7.81(2 \mathrm{H}, \mathrm{d}, \mathrm{J}=8.4)$ for 2 ' and C-6' proton. Shift at $\delta_{\mathrm{H}} 6.77$ for C-8' proton (Fig. 9). The data allowed us to establish apigenin-7-O- $\beta$-glucopyranoside as the structure of the compound by comprising of the spectral data with literature value ${ }^{36}$.

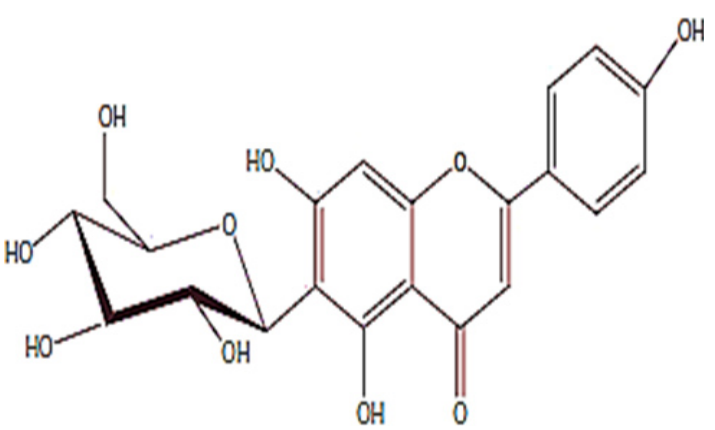

Fig. 4. Chemical structure of compound apigenin-6-C-b-glucopyranoside

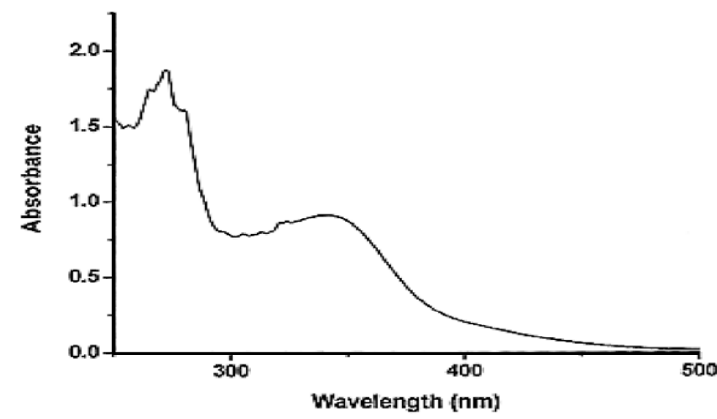

Fig. 5. UV spectrum of apigenin-6-C-b-glucopyranoside

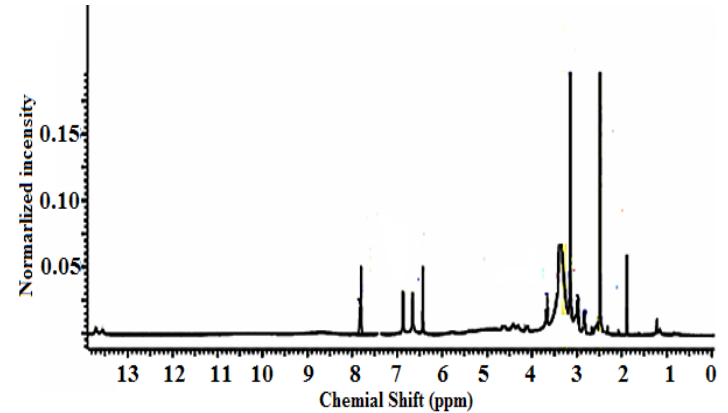

Fig. 6. ' ${ }^{1}$ NMR spectrum of apigenin-6-C-b-glucopyranoside<smiles>O=c1cc(-c2ccc(O)c(O)c2)oc2cc(OC3OC4CC(O)C(O)[C@@H](O)C3O4)cc(O)c12</smiles>

Fig. 7. Chemical structure of compound apigenin-7-0-b-glucopyranoside

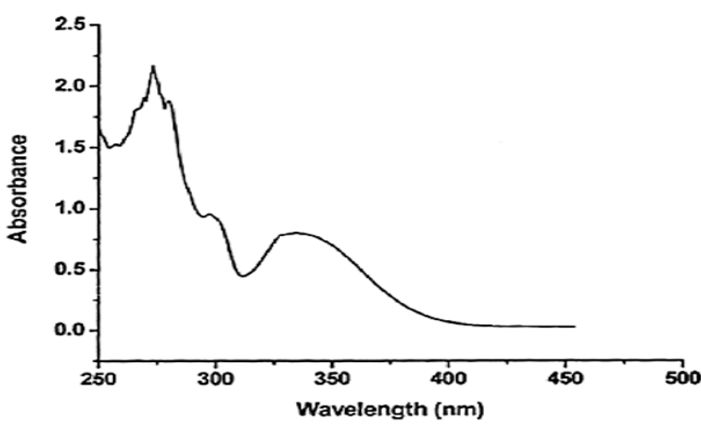

Fig. 8. UV spectrum of apigenin-7-0-b-glucopyranoside

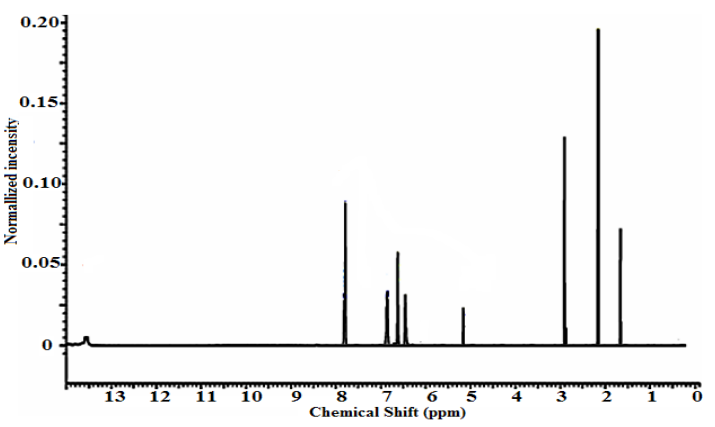

Fig. 9. ${ }^{1} \mathrm{HNMR}$ spectrum of apigenin-7-0-bglucopyranoside

Various methods have been developed for the identification of apigenin and its glucosides in different plants by spectroscopic and chromatographic 
techniques like high-performance thin-layer chromatography ${ }^{37-38}$, HPLC $^{39-42}$ and UHPLC-DAD ${ }^{43}$. Color concentration and high performance liquid chromatographic (HPLC) methods have been used to measure the approximate levels of major flavonoid colorants in sugar mill and refinery products using apigenin as an internal standard.

\section{ACKNOWLEDGMENT}

The author wishes to acknowledge the support of Prof. V. K. Agrawal, Awadhesh Pratap Singh University, Rewa for this work.

\section{Conflict of interest}

The author declares no conflict of interest.

\section{REFERENCES}

1. Smith, P.; Paton, N. H. Sugarcane flavonoids. Sugar. Technol. Rev., 1985, 12,117-142.

2. Yao, L. H., Jiang Y. M.; Shi J, Tomás-Barberán F. A.; Datta, N.; Singanusong, R.; Chen, S.S. Flavonoids in food and their health benefits. Plant. Foods. Hum. Nutr., 2004, 59(3), 113-22.

3. Mc Ghie, T.K. Analysis of sugar cane flavonoids by capillary zone electrophoresis. J Chromatogr., 1993, 634, 107-12.

4. Vila, F.C.; Colombo, R.; de Lira, T.O.;Yariwake, J.H. HPLC microfractionation of flavones and antioxidant (radical scavenging) activity of Saccharum officinarum L. J. Braz. Chem. Soc., 2008, 19, 903-908.

5. De Armas, R.; Martinez, M.; Vincente, C.; Legaz, M.E. Free and conjugated polyamines and phenols in raw and alkaline-clarified sugarcane juice. J. Agric. Food. Chem., 1999, 47, 3086-3092.

6. Colombo, R.; Yariwake, J.H.; Queroz, E.F.; Ndjoko, K.; Hostettmann, K. Online identification of minor flavones from sugarcane juice by LC/UV/MS and postcolumn derivatization. J. Bra. Z. Chem. Soc. 2009, 20, 1574-1579.

7. Takara, K.; Ushijima, K.; Wada, K.; Iwasaki, H.; Yamashita, M. Phenolic compounds from sugarcane molasses possessing antibacterial activity against carcinogenic bacteria. J. Oleo. Sci., 2007, 56, 611-614.

8. Balasundram, N.; Sundram, K.; Samman, S. Phenolic compounds in plants and agriindustrial by-products: Antioxidant activity, occurrence, and potential uses. Food. Chem., 2006, 99, 191-203.

9. Zheng, R.; Su, S.; Li J.; Zhao Z.; Wei J.; Fu, X.; Liu, R.H. Recovery of phenolics from the ethanolic extract of sugarcane (Saccharum officinarum $L$.) baggase and evaluation of the antioxidant and antiproliferative activities. Ind. Crops. Prod., 2017, 107, 360-369.
10. Zhao, Y.; Zhu, L.C.; Yu, S.J.; Zhao, Z.G. HPLCUV-ESI-MS methods for flavonoid profiling of sugarcane juice extract. Sugar. Ind., 2013, 138, 525-531.

11. Farber, L.; and Carpenter, F.G.Plant pigments as colorants in cane sugars', 1972 Tech. Sess. Cane. Sugar. Refining. Res., 1975, 23-31.

12. Kennedy, A.M.; and Smith, P. 'Colour in refineries', Proc. Sugar. Ind. Technol., 1976, 35, 156-160.

13. Dubey, R.C.; and Misra, K. 'Flavonoids of sugarcane', Ind. Chem. Soc., 1974, 51, (6) 653-654.

14. Misra, K. and Mishra, C. S. 'Flavonoids of Saccharum officinarum flowers', Ind. J. Chem., 1979, 18B, 88.

15. Mishra, C.S.; and Misra, K. '5-7Dimethylapigenin 4'-0-D-glucopyranoside from Saccharum officinarum leaves', Curr. Sci., 1978, 47(5), 152.

16. Mabry, T.J.; Liu, Y.L.; Pearce, J.; Dellamonica, G.; Chopin, J.; Markham, K.R.; Paton, N.H. and Smith, P. 'New flavonoids from sugarcane (Saccharum)', J. Nat. Prod., 1984, 47(1) 127-130.

17. Yang, S.H.; Liao, P.H.; Pan, Y.F.; Chen, S.L.; Chou, S.S.; Chou, M.Y. The novel p53-dependent metastatic and apoptotic pathway induced by vitexin in human oral cancer OC2 cells. Phytother. Res., 2013, 27, 1154-1161.

18. Borghi, S.M.; Carvalho, T.T.; StaurengoFerrari, L.; Hohmann, M.S.; Pinge-Filho, P., Casagrande, R.; Verri Jr.; W.A. Vitexin inhibits inflammatory pain in mice by targeting TRPV1, oxidative stress, and cytokines. J. Nat. Prod., 2013, 76, 1141-1149.

19. Krcatovic, E.; Rusak, G.; Bezic, N.; Krajacic, M. Inhibition of tobacco mosaic virus infection by quercetin and vitexin. Acta. Virol., 2008, 52, 119-124. 
20. Bahareh, A.N.; Farid, H.; Mohtaram, A.; Marjan, N.A. Anti-inflammatory effects of quercetin and vitexin on activated human peripheral blood neutrophils. J. Pharmacopuncture., 2017, 20, 127-131.

21. Gaitan, E.; Cooksey, R.C., Legan, J.; Lindsay, R.H. Antithyroid effects in vivo and in vitro of vitexin: a C-glucosyl 12 flavones in millet. J. Clin. Endocrinol. Metab., 1995, 80, 1144-1147.

22. Prabhakar, M.C.; Bano, H.; Kumar, I.; Shamsi, M.A.; Khan, M.S. Pharmacological investigations on vitexin. Planta. Med., 1981, 43, 396-403.

23. Hoffmann-Bohm, K.; Lotter, H.; Seligmann, O.; Wagner, H. Antihepatotoxic Cglycosylflavones from the leaves of Allophyllus edulis var. edulis and gracilis. Planta. Med., 1992, 58, 544-548.

24. Havsteen, B. H. The Biochemistry and Medical Significance of the Flavonoids. Pharmacol. Ther., 2002, 96(2-3), 67-202.

25. Srivastava, J. K.; Gupta, S. Antiproliferative and apoptotic effect of chamomile extract in various human cancer cells. J. Agric. Food. Chem., 2007, 55, 9470-9478.

26. Czubinski, J.; Dwiecki, K.; Singer, A.; Kachlicki, P. Release of flavonoids from lupin globulin proteins during digestion in a model system. J. Agric. Food. Chem., 2012, 60, 1830-1836.

27. Hamon, M., Herbal Medicine.The chamomiles, Can. Pharm. J., 1989, 122, 612-615.

28. Patel, D.; Shukla, S.; Gupta, S. Apigenin and cancer chemoprevention: progress, potential and promise (review). Int. J. Oncol., 2007, 30, 233-245.

29. Wu, K.; Yuan, L.H.; Xia, W. Inhibitory effects of apigenin on the growth of gastric carcinoma SGC-7901 cells, World. J. Gastroenterol., 2005, 11, 4461-4464.

30. Aziba, P.I.; Adedeji, A.; Ekor, M.Analgesic Activity of Peperomia Pellucida Aerial Parts in Mice. Fitoterapia., 2001, 72(1), 57-58.

31. Ragasa, C.Y.; Dumato, M.; Rideout, J.A. Antifungal compounds from Peperomia pellucid. Chem. Res. Commun (ACGC)., 1998, 7, 54-61

32. Xu, S.; Li, N.; Ning, M.M. Bioactive Compounds from Peperomia Pellucida. J. Nat. Prod., 2006,
69(2), 247-250.

33. Williams, C. A.; Harborne, J.B.; Smith, P.The taxonomic significance of leaf flavonoids in Saccharum and related genera. Phytochem., 1974, 13(7), 1141-1149.

34. Chopin, J.; Dellamonica, G.; Harborne, J. B. The Flavonoids, Advances in Research since. Chapman \& Hall, London., 1980, 63, 1988.

35. Yinrong, L.; Yeap, F. Polyphenolic constituents of blackcurrant seed residue. Food. Chem., 2003, 80, 71-76.

36. Mabry, T.J.; Markham, K.R.; Thomas, M.B. The Systematic Identification of Flavonoids. (Springer-Verlag, New York 1970).

37. Aussavashai, S.; Donruedee, S.; Phanchana, S.; Ian, H.F.; Nalin, W. Quantitative determination of vitexin in Passiflora foetida Linn. Leaves using HPTLC. Asian. Pac. J. Trop. Biomed., 2016, 6, 216-220.

38. Shivraj, H. N., Se, W.P. HPTLC densitometry method for simultaneous determination of flavonoids in selected medicinal plants. Front. Life. Sci., 2015, 8, 97-103.

39. Jin, W.; Feng, T.; Yongde, Y.; Xuefeng, G.; Xi, Y. 2010. Development and validation of an HPTLC method for simultaneous quantitation of isoorientin, isovitexin, orientin, and vitexin in bamboo-Leaf flavonoids. J. AOAC. Int., 2010, 93, 1376-1383.

40. Chang-He, W.; Yu-Xuan, W.; Hai-Jing, L. Validation and application by HPLC for simultaneous determination of vitexin-200O-glucoside, vitexin-200-Orhamnoside, rutin, vitexin, and hyperoside. J. Pharm. Anal., 2011, 1, 291-296.

41. Sagaradze, V.; Babaeva, E.; Kalenikova, E. HPLC-UV method for determining flavonoids in hawthorn flowers and leaves. Pharm. Chem. J., 2017, 51, 277-280.

42. Liu, Z.;Wang, L.; Li, W.; Huang, Y. Determination of orientin and vitexin in Trollius chinesis preparation by HPLC. Chi. J. Chin. Mat. Med., 2004, 29(11), 1049-1051.

43. Paula, S.; Geison, M.C.; Diana, M.A.; Freddy, R.; Leonardo, C. Analysis of vitexin in aqueous extracts and commercial products of Andean Passiflora species by UHPLC-DAD. J. Appl. Pharm. Sci., 2018, 8, 81-86. 